\title{
Enhancement of Anticarcinogenic Potentials of Submerged-Liquid Culture of Agaricus blazei Murill on Mouse Ascites Cancer by Rice Hull
}

\author{
Young S. Kim ${ }^{1}$, Wook J. Jang ${ }^{1}$, Md. A. Rakib ${ }^{1}$, Jung M. Kwon ${ }^{1}$, Chae R. Ahn ${ }^{1}$, So Y. Kim ${ }^{3}$, \\ Yong U. $\mathrm{Cho}^{4}$, Young K. $\mathrm{Ha}^{5}$, Jeong O. $\mathrm{Kim}^{5}$ and Yeong L. $\mathrm{Ha}^{1,2 *}$
}

${ }^{l}$ Division of Applied Life Science (BK21 programs), Institute of Agriculture \& Life Science, Gyeongsang National University, Jinju 660-701, Korea ${ }^{3}$ Department of Food Science, International University of Korea, Jinju 660-759, Korea

${ }^{4}$ Department of Pharmaceutical Engineering, Jinju National University, Jinju 660-758, Korea

${ }^{5}$ HK Biotech. Co., Ltd, Jinju 660-913, Korea

Received July 26, 2010 / Accepted August 27, 2010

\begin{abstract}
The effects of rice hull $(\mathrm{RH})$ powder on the anticarcinogenic activity of submerged-liquid cultures of Agaricus blazei Murill (AB) were assessed for mouse ascites cancers induced by mouse Sarcoma S-180 (S-180) cancer cells. Optimal growth of AB mycelia in the basal liquid culture medium, containing soybean meal, was achieved by culturing at $25^{\circ} \mathrm{C}$ for 5 days, when evaluated by $\beta$-glucan content, Brix, and mycelial weight, relative to other culture conditions. Hot-water extract (HWE) of the submergedliquid culture of $\mathrm{AB}$ mycelia grown at $25^{\circ} \mathrm{C}$ for 5 days exhibited a stronger anticarcinogenic activity, relative to HWE from other culture conditions. No such effects were obtained from AB mycelial cultures by alternative temperature-controlling cultures. Both cytotoxicity for S-180 cells and anticarcinogenic potentials for mouse ascites cancer of the HWE from AB mycelia grown in the basal medium containing $1 \% \mathrm{RH}$ powder for 5 days at $25^{\circ} \mathrm{C}$ were significantly $(\mathrm{p}<0.05)$ enhanced, relative to HWE from the $\mathrm{AB}$ mycelia culture of the basal medium without $\mathrm{RH}$ powder. These results indicate that HWE of submerged-liquid culture of $\mathrm{AB}$ mycelia, incubated in media containing $1 \% \mathrm{RH}$ powder at $25^{\circ} \mathrm{C}$ for 5 days, enhanced anticarcinogenic activity against S-180 cell-induced mouse ascites cancer, and suggest that $\mathrm{RH}$ powder is an excellent ingredient for the improvement of the anticarcinogenic potentials of the submerged-liquid culture of mushroom mycelia.
\end{abstract}

Key words : Agaricus blazei Murill (AB), $\beta$-glucan, mouse ascites cancer, rice hull

\section{서 론}

버섯자실체와 버섯균사체 액체배양 추출물의 생리활성에 대한 많은 연구가 수행되었고, 또한 진행되고 있다[24]. 버섯자 실체 및 버섯균사체에는 다양한 생화학 물질이 함유되어 있지 만 생리활성, 특히, 항암과 관련된 물질은 저분자 화합물이 아닌 고분자 화합물 많다[2,7,13]. 버섯 유래 고분자 다당체와 단백다당체는 암 뿐만 아니라 면역증강, 순환기질환 등의 질 환 예방 및 치료효과가 있는 것으로 보고되고 있다 $[3,6$, $15,18,20,22,26]$.

많은 버섯 중, 국내에서 아가리쿠스버섯 또는 흰들버섯으 로 불리는 신령버섯 (Agaricus blazei Murill; $\mathrm{AB}$ )은 동물실험 에서 고형암에 대한 억제율이 $99.4 \%$, 완전 치유율이 $90 \%$ 인 것으로 보고되었다[21,28,30]. 주 활성 성분은 $\beta$-(1-6)-glucosyl 의 가지를 가진 $\beta-(1-3)$-glucan으로 고형암 뿐만 아니라 복수 암, 결장암, 난소암, 유방암, 폐암, 간암 등에도 효과가 있다고 보고되었다 $[5,7,11,19,21,24,28]$. 또한 $\mathrm{AB}$ 에서 분리한 단백다당

*Corresponding author

Tel : +82-55-751-5471, Fax : +82-55-757-0178

E-mail : ylha@gnu.ac.kr
체는 당질이 $50.2 \%$ 이고 단백질이 $43.3 \%$ 로 이 들 단백질과 다 당의 복합체가 항암활성이 있다고 보고되었다[7,12,24]. 버섯 에서 분리한 $\beta$-glucan 항암성 외 다양한 기능성을 갖는 것으로 보고되었다. 예를 들면, Choi와 Koo [3]는 $\mathrm{AB}$ 의 $\beta$-glucan은 당뇨쥐의 식후혈당의 상승을 억제하는 효과가 있다고 하였으 며, Mizuno 등[21]과 Nakajima 등[22]은 $\beta$-glucan의 면역활성 기능, 항산화능, 생체조직 재생과 치유기능, 항생제, 항균 및 대식세포를 자극하여 돌연변이 세포를 인식하고 공격하는 효 과가 있다고 보고하였다.

Mizuno 등[21]은 버섯균사체로 부터 $\beta$-glucan을 분리하였 고, 그 활성 정도는 고분자 물질의 평균 분자량, 구조 및 용해 도 등에 따라 차이가 있다고 보고하였다. 따라서 버섯자실체 에 비해 버섯균사체의 액체배양은 저비용 - 단시간에 균일한 균사체 배양액을 대량생산 할 수 있고, 이 액체배양물로 부터 유용물질의 추출 및 분리가 간편하여 생리활성물질을 생산할 수 있는 방법이라고 보고되었다[9,10,13,17]. 버섯균사체의 액 체배양은 주로 대두박을 기본으로 한 배지에서 배양을 하고 있지만 항암성이 강한 $\beta$-glucan 및 단백다당체의 함량과 그 구조는 배양조건에 따라 상이하다. 특히, 쌀겨는 배지에 혼합 하여 버섯균을 배양할 때 많이 사용하여 왔지만[8], 왕겨를 버 
섯균사체배양에 사용한 연구는 수행된 적이 없다. 따라서 본 연구에서는 $\mathrm{AB}$ 균사체 액체배양물의 항암성을 증진시키기 위 해 $\mathrm{AB}$ 균사체 기본액체배지에 왕겨가루를 첨가하여 배양하 고, 이들 추출물의 항암성 제고를 연구하였다.

\section{재료 및 방법}

\section{재료}

$\mathrm{AB}$ 균주는 한국버섯종균협회에 등록한 것으로 (쥐 $\mathrm{HK}$ 바이 오텍(Jinju, Korea)에서 분양 받아 사용하였다. 대두박은 태평 양화학(Seoul, Korea), 황백당은 제일제당(Seoul, Korea), $\mathrm{KH}_{2} \mathrm{PO}_{4}, \mathrm{MgSO}_{4} \cdot 7 \mathrm{H}_{2} \mathrm{O}, \mathrm{Na}_{2} \mathrm{SO}_{4}$ 는 Shinyo사(Osaka, Japan) 에서 구입하였다. 왕겨는 시중 정미소에서 구입하여 건조하고 100 mesh 체를 통과한 분말을 사용하였다. DMEM 배지는 Sigma-Aldrich (St. Luois, MO)에서 구입하였다. Female ICR mouse (6 7주령)는 Life science (Daegu, Korea)에서, mouse Sarcoma-180 (S-180) cell은 Korea Cell Line Bank (Seoul, Korea)에서 구입하여 사용하였다. 그 외 사용된 시약은 reagent grade 이상이었다.

\section{배지조성 및 배양조건}

액체배양 배지는 기본배지(황백당 $20 \mathrm{~g} / \mathrm{l}, \mathrm{MgSO}_{4} \cdot 7 \mathrm{H}_{2} \mathrm{O}$ $0.5 \mathrm{~g} / \mathrm{l}, \mathrm{KH}_{2} \mathrm{PO}_{4} 0.5 \mathrm{~g} / \mathrm{l}$, 대두박 $100 \mathrm{ml} / \mathrm{l}$ ) (Control 배지)와, 기본배지에 $1 \%$ 왕겨분말 첨가 배지 $(\mathrm{w} / \mathrm{v})$ 를 사용하였다. 배양 은 발효조(KF-5 1, Kobiotech, Seoul, Korea)를 이용하여 배양 하였다. 배양은 항온배양 $\left(10,20,25,30,37^{\circ} \mathrm{C}\right.$ 에서 각각 3,5 , 7,9 일)과 변온배양을 하였다. 변온배양 $\mathrm{I}$ 은 $25^{\circ} \mathrm{C}$ 에서 5 일간 항온배양 후 $4^{\circ} \mathrm{C}$ 에서 7 일간 배양하고, 다시 $25^{\circ} \mathrm{C}$ 에 3 일간 배양 하였고, 변온배양 $\Pi$ 는 $25^{\circ} \mathrm{C}$ 에서 5 일간 배양 후 $10^{\circ} \mathrm{C}$ 에서 7 일 간 배양하고, 다시 $25^{\circ} \mathrm{C}$ 에 3 일 배양하였다.

\section{AB 버섯균사체 액체배양물의 $\beta-g l u c a n$, Brix 및 균사체 측정}

$\beta$-glucan 함량 측정

$\mathrm{AB}$ 균사체 배양물에 1 배의 물을 가해 $110^{\circ} \mathrm{C}$ 에서 30 분 동안 2 회 반복 추출하고 원심분리(5,000 rpm, 10분)하여 여액을 얻 었다. 여액을 감압농축 하여 3 배의 에탄올 $(95 \%)$ 을 가하고, $4^{\circ} \mathrm{C}$ 에서 24 시간 동안 방치한 다음 $5,000 \mathrm{rpm}$ 에서 10 분간 원심분 리 하여 얻어진 침전물을 5 일 동안 투석한 후 동결 건조하여 무게를 측정하였다.

\section{Brix 측정}

$\beta$-glucan 함량측정을 위해 $110^{\circ} \mathrm{C}$ 로 가열 추출한 여액에 대 해 Brix meter (ATAGO, Japan)를 이용하여 상온에서 측정하 였다.

\section{Mycelia 함량 측정}

$\mathrm{AB}$ 균사체 액체배양물(1 l)을 원심분리(5,000 rpm, 10 분)하
여 균사체를 회수한 다음 $105^{\circ} \mathrm{C}$ 에 건조하여 무게를 측정하였다.

\section{항암성 측정}

\section{시료 조제}

시료는 액체배양물에 1 배의 물을 가해 $110^{\circ} \mathrm{C}$ 에서 30 분 동 안 2회 반복 추출하고 원심분리(5,000 rpm, 10 분)하여 여액을 얻고 이를 20 배 농축 후 freeze-dry하여 사용하였다. 시료는 $\mathrm{AB}$ 균사체를 항온배양 $\left(25^{\circ} \mathrm{C}\right.$ 에서 5 일간 $)$ 한 액체배양물과 변온 배양한 액체배양물이었고, 왕겨첨가 시험에서는 왕겨첨가구 (기본배지+Rice hull $+\mathrm{AB}$ ), 대조구(기본배지 $+\mathrm{AB}$ ), 및 왕겨구 (Rice hull+AB) 액체배양물이었다.

\section{S-180 cell에 대한 독성 실험}

S-180에 대한 세포독성은 Bahn 등[1]의 방법에 준하여 실시 하였다. 시료 $(10 \mathrm{mg} / \mathrm{ml}$ 증류수)를 DMEM 배지로 10 배 희석

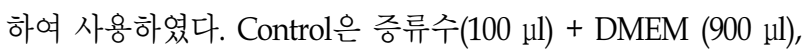
시료처리는 시료 희석액 $(100 \mu \mathrm{ll})+\mathrm{DMEM}(900 \mu \mathrm{l})$ 농도가 되 게 구성하였다. 배양된 S- 180 cell을 $1.5 \times 10^{5} \mathrm{cell} / \mathrm{ml}$ 이 되게 희석하여 $3 \mathrm{ml}$ 부피로 처리한 다음 $\left(5 \times 10^{4} \mathrm{cell} / \mathrm{ml}\right.$ DMEM으로 희석), 처리된 well plate를 $5 \% \mathrm{CO}_{2}$ incubator $\left(37^{\circ} \mathrm{C}\right)$ 에서 48 시 간 동안 배양한 후 trypan blue로 염색하여 hemacytometor로 생세포수를 조사하여 $\mathrm{ED}_{50}$ 값을 구하였다.

\section{Mouse 항복수암성}

Mouse 항복수암 실험은 Bahn 등[1]의 방법에 준하여 실시 하였다. Female ICR mouse (6 7주령, 27 28 g)를 cage당 5 마리씩 분배하고(이때, cage당 평균무게가 같게 임의적으로 넣었다). 온도와 습도가 조절 $\left(25 \pm 1^{\circ} \mathrm{C}, 60 \%\right)$ 되는 시설에 물과 음식을 자유롭게 먹도록 하여 1 주일 동안 적응시켰다. Female ICR mouse 복강에서 계대 배양된 S- 180 cell $\left(1 \times 10^{7} \mathrm{cell} / \mathrm{ml}\right.$ $\mathrm{PBS}$ )을 각 mouse에 $0.1 \mathrm{ml}$ 씩 복강에 주사하여 복수암을 유발 하였다. 복수암 유발 후 2 일마다 시료 $0.1 \mathrm{ml}(500 \mathrm{mg} / \mathrm{ml})$ 을 mouse 복강에 주사하였다. S-180 세포 복강 투여 후 42일 동안 생존한 mouse의 수와 생존일수를 기록하였다.

\section{통계처리}

Data는 mean $\pm \mathrm{SD}$ 로 표시하였으며, 유의성은 one-way 분산 분석(ANOVA)을 통하여 분석한 다음 Duncan의 다중검증으 로 $\mathrm{p}<0.05$ 수준에서 검증하였다.

\section{결 과}

\section{기본액체배지에서 배양조건에 따른 $\mathrm{AB}$ 균사체 생육}

Fig. 1은 $\mathrm{AB}$ 균사체를 기본배지에서 배양온도 $(10,20,25,30$, $\left.37^{\circ} \mathrm{C}\right)$ 와 배양기간 $(3,5,7,9$ 일)에 따른 배양물 중의 $\beta$-glucan 함량을 나타내었다. $\beta$-glucan의 함량은 배양온도와 배양기간 에 따라 많은 영향을 받았다. 배양조건 중에서 $\beta$-glucan을 가 


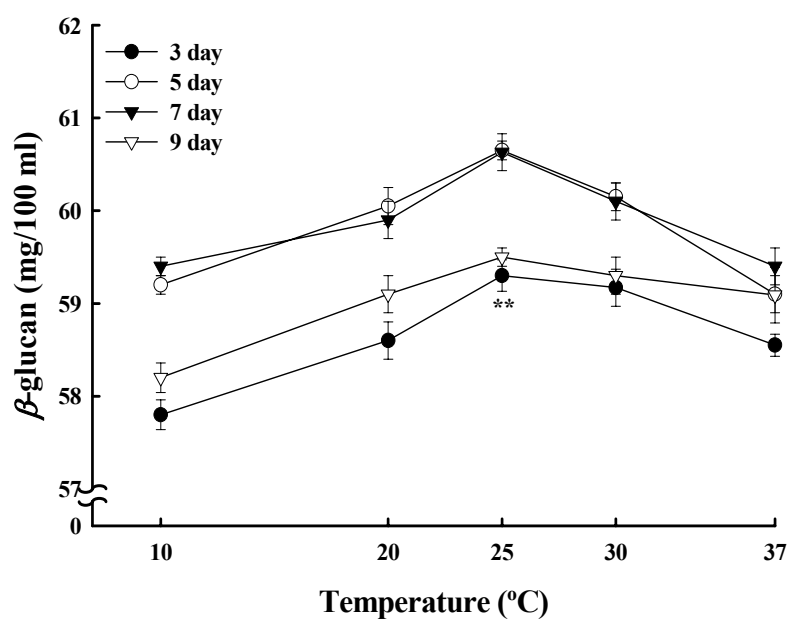

Fig. 1. Contents of $\beta$-glucan produced by the submerged-liquid culture of $\mathrm{AB}$ mycelia at different incubation temperatures and times.

장 많이 생산한 조건은 $25^{\circ} \mathrm{C}$ 에서 5 일간 배양한 경우로 그 함량 이 $60.6 \mathrm{mg} / 100 \mathrm{ml}$ 였다. $25^{\circ} \mathrm{C}$ 를 중심으로 배양온도가 낮아지 거나 높아지는 경우에서 $\beta$-glucan의 함량은 유의적으로 낮아 졌다 $(\mathrm{p}<0.05)$. 또한 배양기간에 따라서는 7 일간 배양하였을 때 의 $\beta$-glucan은 5 일 배양하였을 때의 함량과 차이가 없었다. 그러나 3,9 일간 한 경우 그 함량은 5 일간 배양한 경우보다 유의성 있게 낮았다 $(\mathrm{p}<0.05)$.

Fig. 2는 다양한 조건으로 배양한 $\mathrm{AB}$ 균사체 배양물의 Brix 를 나타내고 있다. Brix는 $25^{\circ} \mathrm{C}$ 에서 5 일간 배양한 경우 $4.19 \%$ 로 가장 높았다. 5 일간 배양한 경우 배양온도에 따라 $25^{\circ} \mathrm{C}$ 로부 터 $37^{\circ} \mathrm{C}$ 로 높아짐에 따라 $0.14 \%$ 감소되었고, $20^{\circ} \mathrm{C}$ 에서는 급격 히 감소되어 그 함량은 $3.85 \%$ 였다. 배양기간에 따른 Brix의 변화는 $25^{\circ} \mathrm{C}$ 에서 5 일간 배양하였을 경우가 가장 높았고, 7 일, 9일 배양한 경우 5 일 간 배양한 것 보다 유의성 있게 감소되었

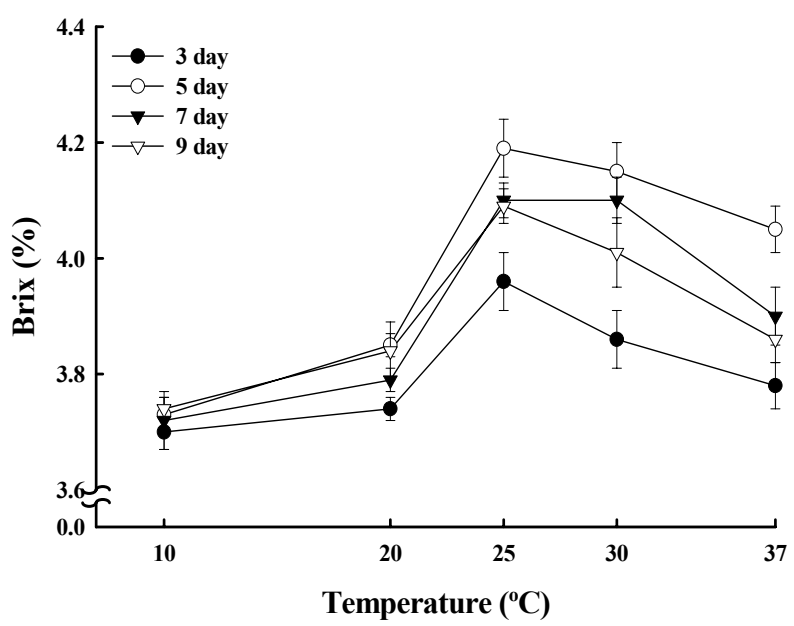

Fig. 2. Changes in Brix of the submerged liquid culture of $A B$ mycelia incubated at different temperatures and times.
다 $(\mathrm{p}<0.05)$. 따라서 배양액의 Brix의 변화는 Fig. 1의 B-glucan 함량 변화와 유사한 패턴을 보여 Brix와 $\beta$-glucan의 함량과는 밀접한 관계가 있음을 의미한다.

B-glucan 함량과 밀접한 관계가 있는 배양액 중의 균사체 함량을 조사하였다(Fig. 3). 배양조건에 따른 균사체의 함량은 Fig. 1이나 2와 유사한 결과를 나타내었다. $25^{\circ} \mathrm{C}$ 에서 5 일간 배 양한 경우의 함량은 $6.14 \mathrm{~g} / 100 \mathrm{ml}$ 로 가장 높았고, 온도가 높 아짐에 따라 감소하여 $37^{\circ} \mathrm{C}$ 에서는 $6.01 \mathrm{~g} / 100 \mathrm{ml}$ 이었다. $25^{\circ} \mathrm{C}$ 이하에서 배양한 경우에는 급격히 감소하여 $20^{\circ} \mathrm{C}$ 에서는 5.76 $\mathrm{g} / 100 \mathrm{ml}$ 이었다. 배양기간이 긴 경우(7일, 9 일)에 $25^{\circ} \mathrm{C}$ 이하에 서는 5 일간 배양한 경우보다 그 함량이 많았으나 $25^{\circ} \mathrm{C}$ 이상에 서는 5 일간 배양한 경우보다 낮았다. 이러한 결과로부터 $25^{\circ} \mathrm{C}$ 에서 5 일간 배양한 액체배양물이 $\beta$-glucan 함량, Brix, 균사체 함량을 최대화시키는 조건임을 알 수 있었다.

$\beta$-glucan의 함량을 증가시킬 목적으로 변온조건에 따른 $\beta$ glucan 함량을 조사하였다(Table 1). $25^{\circ} \mathrm{C}$ 에서 5 일간 항온배양 (control)한 액체배양물을 두 가지 변온 조건에서 배양하였다. 변온배양 I은 control 액체배양물을 $4^{\circ} \mathrm{C}$ 에서 7 일간 배양하고 다시 $25^{\circ} \mathrm{C}$ 에서 3 일간 배양하였고, 변온배양 II는 control 배양 물을 $10^{\circ} \mathrm{C}$ 에서 7 일간 배양하고 다시 $25^{\circ} \mathrm{C}$ 에서 3 일 배양하였다 (Table 1). $\beta$-glucan 함량은 변온배양 I에서 $69.3 \mathrm{mg} / 100 \mathrm{ml}$ 로 서 control 처리보다 유의성 있게 증가하였다. 변온배양 II의 B-glucan $(67.6 \mathrm{mg} / 100 \mathrm{ml})$ 도 control보다 유의성 있게 증가하 였지만, 변온배양 I과는 차이가 없었다. Brix는 처리구간에 유 의성이 없었고, 균사체의 함량도 큰 차이가 없었다. 따라서 배양을 $4^{\circ} \mathrm{C}$ 나 $10^{\circ} \mathrm{C}$ 로 변온배양 함으로써 $\beta$-glucan의 함량을 각각 $14.3 \%, 11.6 \%$ 증가 시킬 수 있었다.

\section{기본액체배지 배양조건에 따른 $\mathrm{AB}$ 균사체 배양물의 항복수암}

$25^{\circ} \mathrm{C}$ 항온에서 5 일 배양 한 배양물과 변온배양 I, I 에서 배양한 배양액의 S-180 cell에 대한 독성은 항온에서 5일간 배

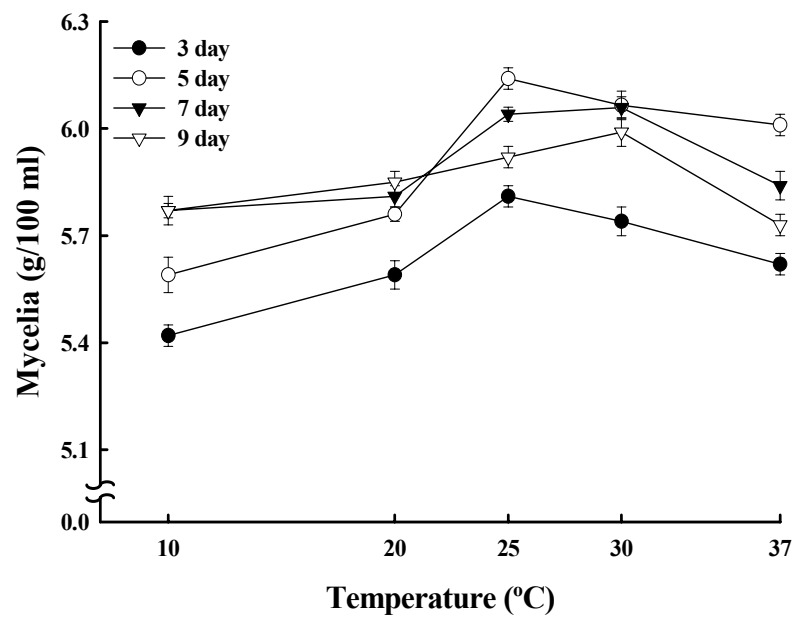

Fig. 3. Dry weight of AB mycelia in the submerged-liquid culture at different incubation temperatures and times. 
Table 1. Effect of cultural conditions on the contents of $\beta$-glucan, Brix and mycelia of the submerged-liquid culture of $A B$ mycelia

\begin{tabular}{ccccc}
\hline Culture condition $^{1)}$ & B-Glucan $(\mathrm{mg} / 100 \mathrm{ml})$ & Brix $(\%)$ & Mycelia $(\mathrm{g} / 100 \mathrm{ml})$ & $\mathrm{ED}_{50}{ }^{2)}(\mu \mathrm{gg} / \mathrm{ml})$ \\
\hline Constant culture & $\left.60.6 \pm 0.3^{\mathrm{a} 3}\right)$ & $4.1 \pm 0.2^{\mathrm{a}}$ & $6.14 \pm 0.04^{\mathrm{a}}$ & $1.5 \pm 0.2^{\mathrm{a}}$ \\
I $\left(25-4-25^{\circ} \mathrm{C}\right)$ & $69.3 \pm 1.5^{\mathrm{a}}$ & $4.3 \pm 0.1^{\mathrm{a}}$ & $6.28 \pm 0.03^{\mathrm{b}}$ & $1.6 \pm 0.3^{\mathrm{a}}$ \\
II $\left(25-10-25^{\circ} \mathrm{C}\right)$ & $67.6 \pm 0.8^{\mathrm{a}}$ & $4.2 \pm 0.1^{\mathrm{a}}$ & $6.09 \pm 0.03^{\mathrm{a}}$ & $1.9 \pm 0.3^{\mathrm{a}}$ \\
\hline
\end{tabular}

${ }^{1)}$ Constant culture: incubation at $25^{\circ} \mathrm{C}$ for 5 days; I $\left(25-4-25^{\circ} \mathrm{C}\right)$ : incubation at $25^{\circ} \mathrm{C}$ for 5 days, $4^{\circ} \mathrm{C}$ for 7 days, and $25^{\circ} \mathrm{C}$ for 3 days in the order; and $\Pi\left(25-10-25^{\circ} \mathrm{C}\right)$ : incubation at $25^{\circ} \mathrm{C}$ for 5 days, $10^{\circ} \mathrm{C}$ for 7 days, and $25^{\circ} \mathrm{C}$ for 3 days in the order.

${ }^{2)} \mathrm{ED}_{50}$ represents an effective dose at $50 \%$.

${ }^{3)}$ Average \pm S.D. of triplication. Means followed by the different letter in same column are significantly different $(p<0.05)$ by Duncan's multiple test.

양된 배양물의 $\mathrm{ED}_{50}$ 값은 각 $1.5 \mu \mathrm{g} / \mathrm{ml}$ 이었고, 변온배양 I 과 П에서 배양된 배양물의 $\mathrm{ED}_{50}$ 값은 각각 $1.6 \mu \mathrm{g} / \mathrm{ml}, 1.9 \mu \mathrm{g} / \mathrm{ml}$ 로 5일간 배양된 배양물과는 차이가 없었다(Table 1). 따라서 변온에 의해 생산된 배양물의 세포독성은 5 일간 배양된 배양 물과 차이가 없음을 의미 하였다.

$25^{\circ} \mathrm{C}$ 항온배양과 변온배양 I과 II에서 생산된 배양물의 S-180 세포로 유발한 mouse 복수암의 항암성을 조사하였 다(Table 2). 평균수명은 $25^{\circ} \mathrm{C}$ 에서 5 일간 배양된 배양물이 32.5 일로 PBS만 처리한 control 처리구 22.1일에 비해 약 $45.7 \%$ 의 수명연장 효과를 나타내었고, 변온배양 I 이 27.3 일, 변온배양 $\Pi$ 가 25.6 일로 약 $20 \%$ 이상의 수명연장 효과 를 나타내었다. 또한 $25^{\circ} \mathrm{C}$ 항온에서 5 일간 배양된 배양물 이 40 일간 최종 3 마리가 살아남아 $30 \%$ 의 생존율을 보였으 며, 변온배양 I, ㅁㄴ는 최종 1 마리가 생존하여 $10 \%$ 의 생존 율을 타나내었다.

\section{왕겨가루 첨가에 의한 항복수암 증가}

기본배지에서 $25^{\circ} \mathrm{C}$ 에서 5 일간 항온 배양한 $\mathrm{AB}$ 균사체 배 양물이 S-180세포로 유발한 mouse 복수암에 대한 항암성이 강하였다(Table 2). 이 배양물의 항암성을 증가시키기 위해 기본배지에 왕겨분말 $1 \%$ 를 첨가하고 $25^{\circ} \mathrm{C}$ 에서 5 일간 배양 하고, 배양물의 B-glucan 함량, Brix, 균사체 무게, S-180 cell 의 세포독성을 조사하였다(Table 3). 왕겨첨가구의 B-glucan $59.8 \mathrm{mg} / 100 \mathrm{ml}$, Brix 4.1\% 및 균사체무게 $6.0 \mathrm{~g} / 100 \mathrm{ml}$ 가 대조구나 왕겨구보다 유의성 있게 높았다 $(\mathrm{p}<0.05)$. 또한 S-180세포에 대한 세포독성도 왕겨첨가구 $1.0 \mu \mathrm{g} / \mathrm{ml}$ 로 대조 구의 $11.0 \mu \mathrm{g} / \mathrm{ml}$, 왕겨구의 $2.3 \mu \mathrm{g} / \mathrm{ml}$ 보다 유의성 있게 높았 다 $(\mathrm{p}<0.05)$.

Table 4 는 왕겨( $1 \%)$ 를 첨가한 $\mathrm{AB}$ 균사체 배양액의 S- 180 cell로 유발한 mouse 복수암에 대한 항암성을 나타내고 있다. 왕겨첨가구의 평균수명은 30.1일로 control 처리구의 평균수

Table 2. Effect of cultural conditions on the S-180 cell-induced mouse ascites cancer of the submerged liquid culture of $\mathrm{AB}$ mycelia

\begin{tabular}{|c|c|c|c|c|}
\hline \multirow{2}{*}{ Parameter ${ }^{1)}$} & \multirow{2}{*}{ Control } & \multirow{2}{*}{$\begin{array}{c}\text { Constant- } \\
\text { temperature culture }\end{array}$} & \multicolumn{2}{|c|}{ Alternative temperature-controling culture ${ }^{3)}$} \\
\hline & & & I $\left(25-4-25^{\circ} \mathrm{C}\right)$ & II $\left(25-10-25^{\circ} \mathrm{C}\right)$ \\
\hline Mean survival day & 22.1 & 32.5 & 27.3 & 25.6 \\
\hline Survival rate $(\%)$ & 100 & 145.7 & 124.8 & 120.6 \\
\hline Survived mouse & 0 & 3 & 1 & 1 \\
\hline
\end{tabular}

${ }^{1)}$ Each treatment was consisted of 10 mice. All the sample containing $100 \mathrm{mg} / 0.2 \mathrm{ml} \mathrm{PBS} /$ mouse. Mean survival day represents mouse numbers survived until 42 days after treatment. Survival rate $=[$ mean survival days of treatment mice/mean survival days of control mice] $\times 100$. Survived mouse represent mouse numbers survived until 42 days after treatment.

${ }^{2)}$ Cultured at $25^{\circ} \mathrm{C}$ for 5 days.

${ }^{3)} \mathrm{I}\left(25-4-25^{\circ} \mathrm{C}\right)$ : incubation at $25^{\circ} \mathrm{C}$ for 5 days, $4^{\circ} \mathrm{C}$ for 7 days, and $25^{\circ} \mathrm{C}$ for 3 days in the order; and $I$ (25-10-25 $\left.\mathrm{C}\right)$ : incubation at $25^{\circ} \mathrm{C}$ for 5 days, $10^{\circ} \mathrm{C}$ for 7 days, and $25^{\circ} \mathrm{C}$ for 3 days in the order.

Table 3. Effect of the rice hull on the growth of submerged-liquid culture of $A B$ mycelia and $\mathrm{ED}_{50}$ value for S-180 cells

\begin{tabular}{lcccc}
\hline \multicolumn{1}{c}{ Treatment } & B-glucan $(\mathrm{mg} / 100 \mathrm{ml})$ & Brix $(\%)$ & Mycelia $(\mathrm{g} / 100 \mathrm{ml})$ & $\mathrm{ED}_{50}{ }^{1)}(\mu \mathrm{g} / \mathrm{ml})$ \\
\hline Basal media + Rice hull $+\mathrm{AB}$ & $59.8 \pm 1.5^{\mathrm{a} 2)}$ & $4.1 \pm 0.1^{\mathrm{a}}$ & $6.0 \pm 0.5^{\mathrm{a}}$ & 1.0 \\
Basal media $+\mathrm{AB}$ & $54.6 \pm 1.7^{\mathrm{b}}$ & $3.8 \pm 0.1^{\mathrm{b}}$ & $5.4 \pm 0.8^{\mathrm{a}}$ & 11.0 \\
Rice hull $+\mathrm{AB}$ & $56.2 \pm 1.4^{\mathrm{b}}$ & $3.9 \pm 0.1^{\mathrm{b}}$ & $5.6 \pm 0.4^{\mathrm{a}}$ & 2.3 \\
\hline
\end{tabular}

${ }^{1)}$ DMEM was used for culture of S-180 cells as a medium.

${ }^{2)}$ Average \pm S.D. of triplication. Means followed by the different letter in same column are significantly different $(p<0.05)$ by Duncan's multiple test. 
Table 4. Effect of rice hull on the S-180 cell-induced mouse ascites cancer of the submerged-liquid culture of AB mycelia

\begin{tabular}{|c|c|c|c|}
\hline Treatment $^{1)}$ & Mean survival day ${ }^{2)}$ & Survival rate $(\%)^{3)}$ & Survival Mouse $^{4)}$ \\
\hline Control & 20.1 & 100 & 0 \\
\hline Basal media + Rice hull $+\mathrm{AB}$ & 30.1 & 149.8 & 4 \\
\hline Basal media $+\mathrm{AB}$ & 24.1 & 119.9 & 1 \\
\hline Rice hull + $\mathrm{AB}$ & 26.7 & 132.8 & 2 \\
\hline
\end{tabular}

${ }^{1)}$ Each treatment was consisted of 10 mice. All the sample containing $100 \mathrm{mg} / 0.2 \mathrm{ml} \mathrm{PBS} /$ mouse. Control mice were given S-180 cells and PBS.

${ }^{2)}$ Average survival days of mouse until 42 days after treatment.

${ }^{3)}$ Survival rate $=[$ mean survival days of treatment mice $/$ mean survival days of control mice $] \times 100$.

${ }^{4)}$ Numbers of mouse survived until 42 days after treatment.

명 20.1보다 $49.8 \%$ 의 수명 연장효과를 나타내었고, 42 일간 최 종 4 마리가 생존하여 $40 \%$ 의 생존율을 보였다. 또한 왕겨구의 평균 수명은 26.7 일로 $32.8 \%$ 의 수명 연장효과를 나타내었으 며, 최종 2 마리가 생존하여 $20 \%$ 의 생존율을 나타내었다.

\section{고 찰}

본 연구에서는 왕겨분말이 대두박을 기본으로 한 액체배지 에 $25^{\circ} \mathrm{C}$ 에서 5 일간 배양한 $\mathrm{AB}$ 균사체배양 추출물의 mouse 복 수암 억제율이 증가하였음을 입증하였다. 또한 항암성을 증가 시키기 위하여 배양온도를 변화시키는 변온방법을 사용하였 지만, 큰 효과는 없었다.

버섯균사의 생장은 품종에 따라 다소의 차이가 있으나, 생 장 온도범위는 품종에 관계없이 $5-32^{\circ} \mathrm{C}$ 이며, $32^{\circ} \mathrm{C}$ 이상에서는 버섯균의 생장이 정지 되어 최적 온도는 $22-26^{\circ} \mathrm{C}$ 라 하였고, 온도에 따른 생장 차이와 균사체가 생성하는 $\beta$-glucan 함량이 달라진다고 하였다[27]. 본 연구에서 $\mathrm{AB}$ 균사체의 생육은 $25^{\circ} \mathrm{C}$ 에서 $\beta$-glucan 함량, Brix 및 균사체 함량이 가장 많아 (Figs. 1-3) Sung 등[27]의 보고와 일치한다. 또한 본 연구결과 는 Lin과 Yang [17]이 보고한 $\mathrm{AB}$ 균사체의 적정 생육온도는 배양조건에 따라 상이하지만, $\mathrm{AB}$ 균사체 생산량에 근거하여 $25-30^{\circ} \mathrm{C}$ 라고 한 보고와 일치한다.

변온배양은 버섯균사체 생장에 stress를 주어 균사의 생장 이나 $\beta$-glucan의 함량을 증기시킨다고 보고하였고[23], $\beta$ glucan이 S-180 cell과 같은 allogenic 및 syngenic tumor에 효 과가 높은 것으로 보고되었다[25]. 본 연구에서 변온배양은 $\mathrm{AB}$ 균사체의 생장에는 큰 영향을 미치지 못하였고, $\beta$-glucan 함량과 Brix는 증가시켰으나(Table 1), S-180 복수암세포에 대 한 독성과 S-180 세포로 유발한 항암성에는 항온 $\left(25^{\circ} \mathrm{C}\right)$ 에서 배양한 배양물과는 큰 차이가 없었다(Table 2). 이와 같은 결과 는 변온에 의한 $\beta$-glucan의 생성량은 증가되었지만, 항암성과 는 큰 관계가 없는 것으로 추정되고, 이에 대한 추가적인 연구 가 필요하다.

대두박을 기본으로 한 기본배지에 왕겨분말 $1 \%$ 첨가하여 배양한 $\mathrm{AB}$ 균사체 배양 추출물에는 $\beta$-glucan 함량이 증가되었
고(Table 3) 항암성도 증가하였다(Table 4). 농산물이나 농산 부산물을 이용하여 버섯균사체를 배양하여 버섯균사체의 생 장을 촉진시켜 균사체의 생산량을 증가시킨 연구는 수행되었 으나[8], 왕겨를 버섯균사체 액체배양에 이용한 경우는 문헌상 찾아 보기 쉽지 않다. Choi와 Park [4]은 벼를 도정하여 얻은 왕겨는 조섬유가 7 $11 \%$, 가용성 당질이 $34 \sim 52 \%$, 회분이 7 $10 \%$, 탄수화물이 $14 \%$, hemicellulose를 비롯한 식이섬유와 inositol, choline, niacin, tocopherol, thiamine $\left(\mathrm{B}_{1}\right)$, pantothenic acid 등 vitamin류가 풍부하다고 보고 하였고, 왕겨에서 추출 한 페룰산이 강한 항산화력을 나타내고, 피틴산은 암세포의 신호체계를 혼란시켜 이상 증식을 억제하고 항암효과를 나타 낸다고 보고하였다. 또한 왕겨에는 강력한 항암물질인 arbinoxylan의 전구체인 hemicellulose가 함유되어 있다[4,16,29]. 본 연구에서 왕겨를 이용하여 배양한 $\mathrm{AB}$ 균사체배양물의 항 암성이 증가된 것은 왕겨에 함유된 화합물이 $\mathrm{AB}$ 균사체의 생 육 중 B-glucan의 함량 또는 구조에 변화를 줄 수 있을 것으로 추정된다. 또한 왕겨의 hemicellulose가 가수분해 되어 많은 양의 arabinoxylan이 생성되어 B-glucan과 함께 synergy 효과 를 보여 줄 수도 있을 뿐만 아니라 고분자 $\beta$-glucan이 중 - 저 분자로 전환되어 항암효과가 증가 되었을 것으로 추정한다 $[14,25,29]$. 그러나 일련의 결과에 대한 구체적인 연구가 더 수 행되어야 할 것이다.

결론적으로 $\mathrm{AB}$ 균사체를 대두박을 기본으로 한 액체배지 에 왕겨분말 $1 \%$ 를 첨가하여 $25^{\circ} \mathrm{C}$ 에서 5 일간 배양함으로서 $\mathrm{AB}$ 균사체 액체배양물의 S-180 cell로 유도한 moue 항복수암 성을 증가시킬 수 있었다. 따라서 이 방법은 다른 버섯균사체 의 액체배양 시 항암성을 증가시킬 목적으로 활용할 수 있을 것이다.

\section{감사의 글}

본 연구는 경상대학교 BK21 지원사업과 한국연구재단 (2009-0075483)의 사업비로 연구되었음을 감사드립니다. 


\section{References}

1. Bahn, K. N., E. J. Lee, M. S. Yang, J. O. Kim, and Y. L. Ha. 1995. Potent anticarcinogenic action of Moutan radix for mouse ascites cancer induced by mouse Sarcoma 180 cells. Agric. Chem. Biotechnol. 38, 364-369.

2. Chang, H. L., G. R. Chao, C. C. Chen, and J. L. Mau. 2001. Non-volatile taste components of Agaricus blazei, Antrodia camphorata and Cordyceps militaris mycelia. Food Chem. 74, 203-207.

3. Choi, J. M. and S. J. Koo. 2000. Effects of B-glucan from Agaricus blazei Murill on blood glucose and lipid composition in db/db mice. Korean J. Food Sci. Technol. 32, 1418-1425.

4. Choi, H. C. and S. J. Park. 2003. Element compositions of rice hull and rice husk ash in Korea. Korean J. Nutri. 36, 352-358.

5. Dong, Q., J. Yao, X. T. Yang, and J. N. Fang. 2002. Structural characterization of water-soluble $\beta$-D-glucan from fruiting bodies of Agaricus blazei Murr. Carbohydrate Res. 337, 417-1421.

6. Franz, G. 1989. Polysaccharides in pharmacy: current applications and future concepts. Planta Med. 55, 493-497.

7. Itoh, H., H. Amano, and H. Noda. 1994. Inhibitory action of a $(1 \rightarrow 6)$ - $\beta$-D-glucan-protein complex isolated from Agaricus blazei Murill on metha fibrosarcoma-bearing mice and its antitumor mechanism. Jpn. J. Pharmacol. 66, 265-271.

8. Jhune, C. S., G. P. Kim, and C. W. Shin. 2000. Effect of rice bran added at spawn-making on the cultivation of Oyster mushroom, Pleurotus spp. Korean J. Mycology 28, 1-5.

9. Jung, I. C., S. H. Kim, Y. I. Kwon, and J. S. Lee. 1996. Cultural Condition for the mycelial growth of Ganoderma lucidum on cereals. Korean J. Mycol. 24, 81-88.

10. Kang, A. S., T. S. Kang, S. M. Cho, and S. H. Yu. 2001. Studies on Submerged culture and mycelial components of Naematoloma sublateritium mycelia. Korean J. Mycol. 29, 22-27.

11. Kawagish, H., R. Inagaki, and T. Kanao. 1989. Fraction and antitumor activity of the water- insoluble residue of Agaricus blazei fruiting bodies. Carbohydrate Res. 186, 267-273.

12. Kawagish, H., T. Kanao, R. Inagaki, T. Mizuno, K. Shimura, H. Ito, T. Hagiwara, and T. Nkamura. 1990. Formolysis of a potent antitumor (1-6)- $\beta$-D-glucan-protein complex from Agaricus blazei fruiting bodies and antitumor activity of the resulting products. Carbohydrate Polymers 12, 393-403.

13. Kim, S. W., H. J. Hwang, J. P. Park, Y. J. Cho, C. H. Sang, and J. W. Yun. 2002. Mycelial growth and exo-biopolymer production by submerged culture of various edible mushrooms under different media. Lett. Microbiol. 34, 56-61.

14. Kim, S. J., H. R. Park, E. J. Park, and S. C. Lee. 2007. Cytotoxic and antitumor Activity of momilactone B from rice hulls. J. Agric. Food Chem. 55, 1702-1706.

15. Kuko, K. and H. Nanba. 1996. The effect of Maitake mushrooms on liver and serum lipids. Altern. Ther. Health Med. 2, 62-69.
16. Kumagai, S., N. Hayashi, T. Sakaki, M. Nakada, and M. Shibata. 2004. Fractionation and saccharification of cellulose and hemicellulose in rice hull by hot-compressed-water treatment with two-step heating. J. Japan Inst. Energy 83, 776-78.

17. Lin, J. H. and S. S. Yang. 2006. Mycelium and polysaccharide production of Agaricus blzei Murrill by submerged fermentation. J. Microbiol. immunol. Infect. 39, 98-108.

18. Liu, F., V. E. Ooi, and S. T. Chang. 1997. Free radical scanvenging activities of mushroom polysaccharide extracts. Life Sci. 60, 763-766.

19. Menoli, R. C. R. N., M. S. Mantovani, L. R. Ribeiro, G. Speit, and B. Q. Jordao. 2001. Antimutagenic effects of the mushroom Agaricus blazei Murill extracts on V79 cells. Mut. Res. 496, 5-13.

20. Mizuno, M., M. Morimoto, K. Minate, and H. Tsucjida. 1998. Polysaccharides from Agaricus blasei stimulate lymphocyte T-cell subsets in mice. Biosci. Biotechnol. Biochem. 62, 434-437.

21. Mizuno, T., T. Hagiwara, T. Nakamura, H. Ito, K. Shimura, and T. Sumiya. 1990. Antitumor activity and some properties of water soluble polysaccharides from the fruiting body of Agaricus blazei Murill, Agric. Biol. Chem. 54, 2889-2896.

22. Nakajima, A., T. Ishida, M. Koga, and M. Takeuchi. 2002. Effect of hot water extract from Agaricus blasei Murill on antibody-producing cells in mice. Int. Immunopharmacol. 2, 1205-1211.

23. Park, K. S., J. E. Son, and G. H. Yoon. 2001. Effects of low and alternated temperature treatments on quality of oak mushroom in sawdust. J. Bio-Environ. Control 10, 3-10.

24. Smith, J. E., N. J. Rowan, and S. Richard. 2002. Medicinal mushrooms: a ripidly developing area of biotechnology for cancer therapy and other bioactivities. Biotech. Letter 24, 1839-1845.

25. Sørensen, H. R., A. S. Meyer, and S. Pedersen. 2003. Enzymatic hydrolysis of water-soluble wheat arabinoxylan. 1. Synergy between L-arabinofuranosidases, endo-1,4--xylanases, and xylosidase activities. Biotechnol. Bioeng. 81, 726-731.

26. Sugiyama, K., S. Saeki, and Y. Ishguro. 1992. Hypercholesterolemic activity of ningyotake (Polyporus confleuens) mushroom in rats. J. Jpn. Soc. Nutr. Food Sci. 45, 265-270.

27. Sung, J. M., Y. B. Yoo, and D. Y. Cha. 1998. Mushroom. pp. 3-10, Kyohaksa. Seoul.

28. Wasser, S. P. 2002. Medicinal mushrooms as a source of antitumor and immunomodulating polysaccharides. Appl. Microbiol. Biotechnol. 60, 258-274.

29. Watanabe, T., M. Shida, Y. Furuyama, K. Tsukamoto, T. Nakajima, and K. Matsuda. 1983. Structure of the arabinoxylan of rice hull. Carbohydrate Res. 123, 83-95.

30. Yoshiaki F, K. Hidekazu, O. Koichi, S. Ryo, E. Takusaburo. 1998. Tumoricidal activity of high molecular weight polysaccharides derived from Agaricus blazei via oral administration in the mouse tumor model. Kagaku Kaishi 45, 246-252. 


\section{초록 : 왕겨에 의한 신령버섯균사체 액체배양액의 생쥐 항복수암성 증가}

김영숙 $^{1} \cdot$ 장욱진 $^{1} \cdot$ 라키브 ${ }^{1} \cdot$ 권정민 $^{1} \cdot$ 안채린 $^{1} \cdot$ 김소영 $^{3} \cdot$ 조용운 $^{4} \cdot$ 하영권 $^{5} \cdot$ 김정옥 $^{5} \cdot$ 하영래 $^{1,2 *}$

( ${ }^{1}$ 경상대학교 응용생명과학부(BK21), ${ }^{2}$ 경상대학교 농업생명과학연구원, ${ }^{3}$ 한국국제대학교 식품과학과,

${ }^{4}$ 진주산업대학교 제약공학과, ${ }^{5}$ (주) $\mathrm{HK}$ 바이오텍)

왕겨가 Agaricus blazei Murill (AB: 신령버섯)균사체 액체배양 추출물의 항암성을 증가시키는지에 관한 연구를 수행하였다. $\mathrm{AB}$ 균사체를 대두박을 기본으로 한 액체배지에 다양한 조건으로 배양하여, B-glucan 함량, Brix, 균사 체를 측정하여 적정 생육조건을 선정하고, 이들의 열수추출물의 S-180 cell로 유도한 mouse 복수암에 대한 항암 성을 조사하였다. $\mathrm{AB}$ 균사체는 $25^{\circ} \mathrm{C}$ 에서 5 일간 배양하였을 때 최적 생육을 나타내었고, 이 배양물이 다른 조건에 서 배양한 배양물보다 우수한 항암성을 나타내었다. $\mathrm{AB}$ 균사체의 생육 및 항암성은 변온배양에 따른 효과는 없었 다. 따라서 이 최적배양조건 $\left(25^{\circ} \mathrm{C}, 5\right.$ 일 배양 $)$ 에서 $\mathrm{AB}$ 균사체를 $1 \%$ 왕겨분말이 함유된 액체배지에 배양하고, 이의 열수 추출물의 항암성을 검증하였다. $1 \%$ 왕겨가 함유된 액체배지에서 배양한 열수추출물의 항암성은 왕겨가 함 유되지 않은 배지의 열수추출물보다 항암성이 유의성 있게 증가되었다 $(\mathrm{p}<0.05)$. 왕겨의 첨가는 $\mathrm{AB}$ 균사체의 생육 을 오히려 촉진시켰다. 이 결과는 왕겨가 $\mathrm{AB}$ 균사체 뿐 만 아니라 다른 버섯균사체 액체배양물의 항암성 증진을 위한 원료로 활용될 수 있을 것임을 의미한다. 